\title{
2013 Korean Society of Hypertension guidelines for the management of hypertension: part III-hypertension in special situations
}

\author{
Jinho Shin ${ }^{1}$, Jeong Bae Park², Kwang-il Kim, Ju Han Kim, Dong Heon Yang ${ }^{5}$, Wook Bum Pyun ${ }^{6}$, \\ Young Gweon Kim ${ }^{7}$ Gheun-Ho Kim ${ }^{1}$, Shung Chull Chae ${ }^{5 *}$ and The Guideline Committee of the Korean Society of \\ Hypertension
}

This article is 3/3, Please see related article 10.1186/s40885-014-0012-3.

\begin{abstract}
Different treatment strategies are suggested for special situations. Hypertension is common in the elderly and frequently accompanied by or complicates other clinical conditions such as metabolic syndrome, coronary artery disease, heart failure, stroke, diabetes mellitus and chronic kidney disease.
\end{abstract}

Keywords: Antihypertensive treatment, Guidelines, Hypertension, Complications

\section{Hypertension in special situations}

White coat hypertension and masked hypertension

Emphasizing out-of-office BP measurements, white coat hypertension (HTN) and masked HTN are acknowledged as new categories of BP by performing ABPM or home BP monitoring. Although the clinical evidence is not established, some expert opinions exist for these two categories. For most subjects with white coat HTN, lifestyle modifications and regular BP monitoring are recommended. Despite the weak evidence, when metabolic disturbance and/or subclinical organ damage occur with white coat HTN, pharmacologic treatment as well as lifestyle modifications could be considered [1,2]. Strict pharmacologic treatment for masked HTN may be beneficial because it showed a similar cardiovascular (CV) risk profile to that of sustained HTN [3].

\section{Metabolic syndrome}

Many hypertensive patients have obesity and metabolic abnormalities with alterations of lipid and glucose metabolism. Furthermore, subclinical organ damage is not

\footnotetext{
* Correspondence: scchae@knu.ac.kr

${ }^{5}$ Division of Cardiology, Department of Internal Medicine, Kyungpook National University School of Medicine, 130 Dongdeok-ro, Jung-gu, Daegu 700-721, Korea

Full list of author information is available at the end of the article
}

uncommon in these patients. Metabolic syndrome involves abdominal obesity, dyslipidemia, dysglycemia, and raised BP. The criteria for clinical diagnosis of metabolic syndrome are 1) abdominal obesity; 2) fasting glucose $\geq 100$ $\mathrm{mg} / \mathrm{dL}$ (diabetes included); 3) triglyceride $\geq 150 \mathrm{mg} / \mathrm{dL} ; 4$ ) HDL cholesterol $<40 \mathrm{mg} / \mathrm{dL}$ in men and $<50 \mathrm{mg} / \mathrm{dL}$ in women; and 5) BP $\geq 130 / 85 \mathrm{~mm} \mathrm{Hg}$. Presence of three or more of these criteria confirms the diagnosis of metabolic syndrome [4]. Abdominal obesity is usually estimated by the measurement of waist circumference. However, cut points of waist circumference for abdominal obesity in Korean adults are not established. Cut points of waist circumference, which are commonly used, are 1) $>90 \mathrm{~cm}$ in men; $>80 \mathrm{~cm}$ in women (International Obesity Task Force criteria for Asian-Pacific population) [5] or 2) $\geq 90$ $\mathrm{cm}$ in men; $\geq 85 \mathrm{~cm}$ in women (Korean adult specific values) [6].

The prevalence of metabolic syndrome has been increasing for the past 10 years, as reported in the Korean National Health and Nutritional Survey. Twenty-five to thirty percent of Koreans over 20 years have metabolic syndrome. However, the prevalence of metabolic syndrome is much higher in hypertensive patients, reaching two times that of the adult population [7].

In Western countries, people with metabolic syndrome are at 1.5 to 2 times higher risk of $\mathrm{CV}$ events and death 
than those without metabolic syndrome, [8] and incident diabetes is five times higher in people with metabolic syndrome [9]. In Asian countries, metabolic syndrome had a relative risk of incident diabetes of three to four, which is a little lower compared to that in Western countries $[10,11]$. The most powerful predictor of incident diabetes is hyperglycemia in people with metabolic syndrome. However, metabolic syndrome, even without hyperglycemia, was associated with an increased risk of incident diabetes; the relative risk is 2.4 in Japanese populations [11]. In addition to metabolic syndrome, HTN is a risk factor for incident diabetes, [12] with a relative risk for incident diabetes of two [13,14].

In hypertensive patients with metabolic syndrome, antihypertensive treatment aims mainly to prevent $\mathrm{CV}$ morbidity and mortality, while lowering or preventing incident diabetes. Antihypertensive treatment in non-diabetic patients with metabolic syndrome is discussed below, while that in diabetic/cardiovascular disease (CVD) patients with metabolic syndrome are discussed in other respective sections of the special situations chapter. Lifestyle modifications, especially weight reduction and regular exercise, are strongly recommended in all hypertensive patients, as they decrease BP, improve metabolic abnormalities, and delay incident diabetes.

Antihypertensive drugs to be selected should have adequate BP lowering efficacy, as well as favorable or neutral effects on insulin sensitivity and metabolic abnormalities. Thus, angiotensin-converting enzyme ACE inhibitors, angiotensin receptor blockers (ARBs), and calcium antagonists are preferred. Among beta-blockers, vasodilating beta-blockers such as carvedilol and nebivolol can be selected when angiotensin-converting enzyme inhibitors or angiotensin receptor blockers are avoided. Carvedilol and nebivolol have no unfavorable effects on glucose and lipid metabolism [15-17]. These beta-blockers can be used as combination therapy with angiotensin-converting enzyme inhibitors or angiotensin receptor blockers. However, the BP lowering efficacy is lower with a combination of beta-blockers and angiotensin-converting enzyme inhibitors or angiotensin receptor blockers than with a combination of beta-blockers and calcium antagonists. Old generation beta-blockers such as propranolol, atenolol, and metoprolol are associated with an increased risk of new onset diabetes and unfavorable effects on lipid metabolism $[18,19]$. The long-term use of these drugs as monotherapy needs to consider the risk for new onset diabetes and dyslipidemia.

Thiazides and thiazide-like diuretics are avoided as monotherapy or at high dose but used as combination therapy or at low dose. These diuretics can induce hypokalemia and new onset diabetes and have unfavorable effects on lipid metabolism. Combination with old generation beta-blockers is avoided. They can be used with potassium- sparing diuretics. The preferred approach is combination with angiotensin-converting enzyme inhibitors and angiotensin receptor blockers to minimize their unfavorable effects on glucose and lipid metabolism.

The combination of angiotensin-converting enzyme inhibitors and angiotensin receptor blockers and thiazide diuretics is less favorable in terms of $\mathrm{CV}$ events and incident diabetes than combination of angiotensin-converting enzyme inhibitors or angiotensin receptor blockers and calcium antagonists [20].

\section{Diabetes mellitus}

The prevalence of HTN is twofold in diabetic patients compared to that in the general population, and the occurrence of diabetes is 2.5 times higher in hypertensive patients $[14,19]$. The coexistence of HTN and diabetes causes the progression of CVD, stroke, and renal disease. The high risk of HTN in diabetic patients is known to be due to weight gain and hyperinsulinemia, hyperactivity of sympathetic nervous system, and the increase of body fluids by the renal retention of sodium. Additionally, hyperglycemia further increases the risk of HTN by increasing arterial stiffness and progressing atherosclerosis. The nocturnal dipping disappears in diabetic patients, and it is related with subclinical organ damage such as left ventricular hypertrophy (LVH) and microalbuminuria. In UKPDS-36, each $10 \mathrm{~mm} \mathrm{Hg}$ decrease in mean systolic blood pressure (SBP) was associated with risk reductions of $12 \%$ for any complication related to diabetes, $15 \%$ for deaths related to diabetes, $11 \%$ for myocardial infarction, and $13 \%$ for microvascular complications [21]. Previous studies show that appropriate BP control can reduce the incidence of CVD [22-25].

The recommended target for BP in diabetic patients is $<140 / 85 \mathrm{~mm} \mathrm{Hg}$. In previous guidelines, the recommended BP was $<130 / 80 \mathrm{~mm} \mathrm{Hg}$ or $<140 / 80 \mathrm{~mm} \mathrm{Hg}$ in diabetic patients [26]. However, recent studies showed that maintaining a low BP did not result in a reduction of the incidence of CV events [27]. Therefore, the cost-effectiveness and side effects of antihypertensive drugs should be considered when the BP drops excessively in diabetic patients.

According to a recent meta-analysis, all classes of antihypertensive agents, such as ACE inhibitors, ARBs, calcium channel blockers, beta-blockers, and diuretics, are useful [28]. ACE inhibitors and ARBs are recommended as first line antihypertensive therapy in a patient without compelling indications. The superiority of one antihypertensive class over others is controversial. The choice of a particular class is less significant in practice because two or more antihypertensives should be combined in order to obtain sufficient decrease in BP in most diabetic patients. However, the combination of beta-blockers and 
thiazide diuretics needs to be prescribed with caution as it could worsen glucose control by increasing insulin resistance [18].

\section{Hypertension in older adults}

The treatment of HTN in older adults reduces the occurrence of vascular disease and mortality. The benefit of treatment is also observed with regard to isolated systolic HTN. Accordingly, HTN needs to be actively diagnosed and treated in older adults [29].

However, the pharmacological treatment of stage I HTN in patients aged 80 years or older remains undetermined. Thus, the characteristics of the patient should be considered. The characteristic findings in elderly hypertensive patients are increased SBP and pulse pressure due to increased central arterial stiffness. Moreover, atherosclerotic renovascular HTN is commonly observed. Non-dipper, increased daytime BP variability, and orthostatic or postprandial hypotension are also characteristic findings in elderly patients with HTN.

The non-pharmacological treatment in elderly HTN patients is effective; however, the impact on patients' quality of life should be considered [30]. The target SBP for older patients is $<140$ to $150 \mathrm{~mm} \mathrm{Hg}$, but orthostatic hypotension should be avoided [31,32]. Additional studies are required to confirm the target SBP in old or frail patients.

The initial dose of the pharmacologic treatment is reduced by half in younger patients and gradually increased. Elderly hypertensive patients without comorbidities should be treated with ACE inhibitors, angiotensin receptor blockers, calcium antagonists, and diuretics [33-36]. Beta-blockers do not improve prognosis as much as other drug classes in elderly hypertensive patients [37-39]. However, beta-blockers would be effective in patients with angina, heart failure, or tachycardia. Combination therapy with two or more drugs should be considered if the BP is not controlled with monotherapy. Patients with comorbidities require special consideration. It is safe to slowly lower the BP in elderly patients. Complications caused by medication should be monitored when increasing the drug dose. Orthostatic hypotension should be periodically checked by positional BP measurement.

\section{Cardiovascular diseases Coronary artery disease}

HTN is a major risk factor of coronary artery disease and is associated with the occurrence of myocardial infarction [25]. The incidence of ischemic heart disease increases when SBP is $>140 \mathrm{~mm} \mathrm{Hg}$ [40] and mortality increases when SBP is $>120 \mathrm{~mm} \mathrm{Hg}$ [41,42]. Previous guidelines have recommended a target $\mathrm{SBP}<130 \mathrm{~mm} \mathrm{Hg}$ in patients with coronary artery disease, although the level of evidence is weak. Therefore, the present recommended SBP in coronary artery disease is $<140 \mathrm{~mm} \mathrm{Hg}$.

The preferred drugs within 1 month after acute myocardial infarction are beta-blockers [43] and angiotensinconverting enzyme inhibitors [44]. Any first line antihypertensive drugs are available in other types of ischemic heart disease. In the case of symptomatic coronary artery diseases, beta-blockers and calcium antagonists need to be considered first.

\section{Chronic heart failure}

HTN is the most important risk factor in heart failure [45]. Most BP lowering drugs such as diuretics, beta-blockers, ACE inhibitors, and angiotensin receptor blockers are effective in the prevention of heart failure [46]. Low BP in patients with systolic dysfunction and HTN is associated with poor $\mathrm{CV}$ outcomes, despite high BP being a risk factor for heart failure [47]. Few studies have investigated patients with heart failure and low BP because most prospective randomized studies did not include patients with low BP. The appropriate BP is determined based on the patient's situation. However, indirect studies showed that beta-blockers, ACE inhibitors, ARBs, and aldosterone antagonists are useful for modifying the harmful effects of the sympathetic nervous system and renin-angiotensinaldosterone system and are the preferred drugs in patients with heart failure [48]. HTN is also a risk factor for heart failure with preserved left ventricular systolic function. Most studies in patients with preserved heart failure revealed no additional benefits from lowering the SBP below $140 \mathrm{~mm} \mathrm{Hg}$ [49].

\section{Atrial fibrillation}

Atrial fibrillation is frequently observed [50] and preventable with BP control in patients with HTN [51]. Patients with HTN and atrial fibrillation have a high risk of thromboembolism and need chronic antithrombotic treatment if no contraindications are present [52]. Recently, antithrombotics such as the thrombin inhibitors dabigatran, factor Xa inhibitors, rivaroxaban, and apixaban have been shown to be more effective and relatively safe compared with the classic established therapy using warfarin [53]. In patients with atrial fibrillation and HTN, lowering the BP can decrease the incidence of fatal bleeding during antithrombotic treatment [54]. Beta-blockers and non-dihydropyridine calcium antagonists are useful for controlling the heart rate. In patients with HTN and LVH, ACE inhibitors or ARBs are effective for primary prevention of atrial fibrillation [55-59]. However, the benefits of ACE inhibitors are negligible in patients with chronic atrial fibrillation or known atherosclerosis [60-65]. Beta-blockers and aldosterone antagonists are useful for the prevention of atrial fibrillation in patients with heart failure $[65,66]$. 


\section{Other arterial diseases}

\section{Carotid atherosclerosis}

The progression of carotid atherosclerosis is decreased by lowering the BP. For this purpose, calcium antagonists and ACE inhibitors are superior to beta-blockers and diuretics $[67,68]$.

\section{Arterial stiffness}

Most antihypertensive drugs decrease vascular stiffness because lowering the BP decreases vascular wall stress and pulse wave velocity. Other than the BP lowering effect, inhibitors of the renin-angiotensin-aldosterone system decrease the pulse wave velocity, regardless of $\mathrm{BP},[69-71]$ while vasodilating beta-blockers decrease the central aortic SBP compared to that with atenolol [72]. Although an improvement in vascular stiffness with antihypertensive drugs has been reported in numerous studies, it is still uncertain whether the improvement in vascular stiffness is closely related to the $\mathrm{CV}$ benefits, except for patients with specific condition [73]. Further studies are needed to determine the relationship between vascular stiffness and CV outcomes.

\section{Peripheral artery disease}

It is important to control the CVD risk factors because patients with peripheral artery disease have a higher risk of CV mortality (10-year mortality of 40\%) [74]. Lowering the SBP decreases the leg amputation rate and mortality in hypertensive patients with diabetes and peripheral artery disease. The target BP is $<140 / 90 \mathrm{~mm} \mathrm{Hg}$ in patients with peripheral artery disease.

Lifestyle modifications such as salt restriction, weight control, moderation of alcohol intake, and regular aerobic exercise are very important. Pharmacologic treatment consists of ACE inhibitors, ARBs, and aspirin. ACE inhibitors decrease long-term $\mathrm{CV}$ events from either $\mathrm{BP}$ lowering effects or indirect BP lowering effects [25,75]. However, other drugs are also effective in the reduction of $\mathrm{CV}$ events associated with BP lowering [25]. Furthermore, it is important to evaluate and manage CV risk factors other than HTN, such as lipid and blood sugar. The appropriate drugs are determined according to the presence of heart failure or coronary artery disease. Generally, betablockers are relatively contraindicated to avoid worsening of peripheral artery disease symptoms. However, some reports revealed that beta-blockers do not increase the symptoms in patients with mild to moderate peripheral artery disease severity. Therefore, beta-blockers are effective in peripheral artery disease patients with coexisting ischemic heart disease or tachycardia [76-78]. Renal artery stenosis is frequently observed in patients with HTN and peripheral artery disease. Overall, ongoing evaluation of the disease and monitoring are needed during HTN treatment [79].

\section{Chronic kidney disease}

Chronic kidney disease (CKD) is defined by the presence of kidney injury for $\geq 3$ months, with the markers of kidney injury being a decrease in estimated glomerular filtration rate $\left(<60 \mathrm{~mL} / \mathrm{min} / 1.73 \mathrm{~m}^{2}\right)$, urinary abnormalities including albuminuria ( $\geq 30 \mathrm{mg} /$ day or albumin-to-creatinine ratio $\geq 30 \mathrm{mg} / \mathrm{g}$ ), hematuria and pyuria, electrolyte disturbances caused by tubular dysfunction, renal structural abnormalities detected by imaging or biopsy procedures, and renal transplants [80]. CKD patients frequently suffer from HTN; hence, the rate of decline in renal function and the incidence of $\mathrm{CV}$ complications can be reduced with HTN control [81,82]. However, we still need to determine the target BP levels, optimal tools to be used in HTN control, and the real benefits and risks associated with treatment [83].

Previous clinical practice guidelines including the seventh report of the Joint National Committee on the Prevention, Detection, Evaluation, and Treatment of High Blood Pressure (JNC7) and Kidney Disease Outcomes Quality Initiative (KDOQI) recommended a BP target of $<130 / 80 \mathrm{~mm} \mathrm{Hg}$ in all CKD patients $[84,85]$. However, recent major clinical trials failed to show that in nonproteinuric CKD patients, a strict BP target of $<125 / 75$ to $<130 / 80 \mathrm{~mm} \mathrm{Hg}$ is more beneficial than a conventional target of <140/90 mm Hg; [86] hence, we recommend that CKD patients without albuminuria be treated to maintain a BP that is consistently $<140 / 90 \mathrm{~mm} \mathrm{Hg}$ [87-89]. On the other hand, randomized controlled trials suggested that a lower target may be beneficial in proteinuric CKD patients. Thus, we recommend that CKD patients with albuminuria be treated to maintain a $\mathrm{BP}$ that is consistently $<130 / 80 \mathrm{~mm} \mathrm{Hg}$ [90-93]. BP target levels do not depend on the presence of DM [94].

Lifestyle modification should be used as a basic tool for BP control in all hypertensive CKD patients. Although no large scale randomized controlled trials have reported the effects of lifestyle modification on clinical outcomes in CKD patients, the beneficial effects can be inferred from the results reported in previous studies in general populations [95-101]. The 2007 Korea National Health and Nutrition Examination Survey showed that BMI and abdominal obesity were independently associated with the estimated glomerular filtration rate [102]. We recommend achieving or maintaining a healthy weight (BMI, 20 to 25), lowering salt intake to $<90 \mathrm{mmol}$ $(<2 \mathrm{~g})$ per day of sodium unless contraindicated, undertaking regular exercise compatible with $\mathrm{CV}$ health and tolerance, and limiting alcohol intake to $<2$ standard drinks per day for men and $<1$ standard drink per day for women.

Pharmacologic treatment in CKD patients includes single or multiple antihypertensive therapies to achieve the target BP. Although any antihypertensive can be 
used in CKD patients, ACE inhibitors or ARBs have been reported to be renoprotective owing to the reduction in proteinuria and improvement in the rate of decline in glomerular filtration rate [93,103-105]. Thus, as shown in Table 1, we recommend that an ACE inhibitor or ARB be used in CKD patients with albuminuria. ACE inhibitors or ARBs are preferred in both diabetic and nondiabetic CKD patients with either microalbuminuria (range, 30 to $300 \mathrm{mg} /$ day) or macroalbuminuria ( $>300 \mathrm{mg} /$ day).

It should be noted that there are occasions when the BP target and the preferred agent mentioned above may be inappropriate. Treatment should be individualized based on the patient's age, presence of albuminuria, and comorbidities. Diabetic or elderly patients need to be asked about orthostatic dizziness because of the possibility of postural hypotension [106-108]. ACE inhibitors and ARBs are contraindicated in bilateral renal artery stenosis and should be used with caution in patients with diffuse atherosclerosis.

\section{Cerebrovascular diseases}

The risk of ischemic and hemorrhagic stroke increases proportionally as the BP increases, with HTN being the most common adjustable risk factor in stroke prevention and having the highest attributable risk for stroke in the population. HTN treatment, particularly SBP control, will remarkably reduce the incidence of stroke. For the management of high BP, lifestyle modification (weight loss, low-fat diet, reduced salt intake, exercise or physical activity, moderation of alcohol intake, and smoking cessation) must routinely precede drug therapy. According to an epidemiologic study, with each increase of $20 / 10$ $\mathrm{mm} \mathrm{Hg}$ for $\mathrm{BP}>115 / 75 \mathrm{~mm} \mathrm{Hg}$, deaths from stroke increased at least twofold. Conversely, a $10 / 5 \mathrm{~mm} \mathrm{Hg}$ decrease in BP resulted in a $40 \%$ decrease in deaths from stroke [41]. In addition, a meta-analysis of clinical studies showed that the stroke risk was expected to decrease by about $30 \%$ to $40 \%$ by lowering the BP by $10 / 5 \mathrm{~mm}$ $\mathrm{Hg}$ with drug therapy, regardless of the past history of the patient $[43,109,110]$. For the primary prevention of stroke, it is recommended to maintain the BP $<140 / 90$ $\mathrm{mm} \mathrm{Hg}[84,111]$. Although it remains unknown whether a specific drug or class is superior to other antihypertensive drugs in the prevention of stroke, a limited number of reports show that calcium antagonists, ACE inhibitors, or ARBs are superior to beta-blockers [112]. However, for the primary prevention of stroke, it is most important to lower the BP based on an individualized approach for each patient rather than the choice of a specific drug or class of drug [113].

\section{Acute ischemic stroke}

In general, the BP rises in acute ischemic stroke. It is assumed that BP increases owing to the acute stress, previous HTN, and the automatic compensation in an attempt to maintain perfusion of the brain tissue in the ischemic state [114]. Thus, continuous BP monitoring is important, as a sudden drop in BP should be avoided to maintain the appropriate perfusion to the brain. Although a previous study has shown that ARB administration for 1 week in stroke patients within a week of the attack reduced the mortality after a 12-month period, [25] largescale studies are needed to resolve the debates [115]. On the contrary, because active treatment against rising $\mathrm{BP}$ would reduce the perfusion to the ischemic area and expand the area of the infarction, it is undesirable to lower the BP actively within the period of 1 week of the acute ischemic stroke $[18,116]$.

When thrombolytic therapy is used in the hyperacute period of an ischemic stroke, the incidence of bleeding is closely related to the BP before and after thrombolysis; hence, the target BP should be $<185 / 110 \mathrm{~mm} \mathrm{Hg}$. For thrombolytic therapy using t-PA, the drug could only be administered after the BP was $<185 / 110 \mathrm{~mm} \mathrm{Hg}$. The antihypertensive regimens consisting of intravenous drugs such as labetalol, nicardipine, diltiazem, nitroglycerin, and nitroprusside are recommended [117-120].

In the acute phase of the ischemic stroke, it is recommended to use antihypertensive drugs only when BP is $>220 / 120 \mathrm{~mm} \mathrm{Hg}$, to avoid a decrease in the cerebral perfusion around the infarct area [121]. Target BP levels should be $85 \%$ to $90 \%$ of the baseline BP. However, in cases of hypertensive encephalopathy, aortic dissection, acute renal failure, acute pulmonary edema, and acute myocardial infarction, it is recommended to lower the BP sufficiently in order to prevent complications associated with the elevated BP itself $[117,118]$.

\section{Acute parenchymal hemorrhage}

From a theoretical viewpoint, the optimal BP treatment in the acute phase of a parenchymal hemorrhage could prevent re-bleeding and subsequent expansion of a hematoma and edema; hence, it is recommended to lower the BP during the acute phase of the hemorrhage. If the SBP is $\geq 200 \mathrm{~mm} \mathrm{Hg}$ or if the mean BP is $\geq 150$ $\mathrm{mm} \mathrm{Hg}$, the BP should be lowered by monitoring BP

Table 1 Target blood pressure and preferred drugs in hypertension of adult chronic kidney disease patients

\begin{tabular}{lll}
\hline Albuminuria & Blood pressure target $\mathbf{( m m ~} \mathbf{~ g})$ & Preferred drugs \\
\hline No $(<30 \mathrm{mg} /$ day $)$ & $<140 / 90$ & None \\
Yes $(\geq 30 \mathrm{mg} /$ day $)$ & $<130 / 80$ & Angiotensin-converting enzyme inhibitors or angiotensin receptor blockers \\
\hline
\end{tabular}


every $5 \mathrm{~min}$. In patients with increased intracranial pressure, BP should be lowered by maintaining the cerebral perfusion pressure between 60 to $80 \mathrm{~mm} \mathrm{Hg}$ using an intracranial pressure monitoring device only when the $\mathrm{SBP}$ is $>180 \mathrm{~mm} \mathrm{Hg}$ or the mean BP is $>30 \mathrm{~mm} \mathrm{Hg}$. Because a sudden drop of BP during the acute phase is associated with higher mortality rates, it is recommended to maintain a cerebral perfusion pressure of $\geq 60 \mathrm{~mm} \mathrm{Hg}$. When the SBP is $180 \mathrm{~mm} \mathrm{Hg}$ or the mean BP is $130 \mathrm{~mm} \mathrm{Hg}$-as long as there is no evidence of increased intracranial pressure, with the assessment of BP every 15 min - the BP should be lowered below the level of $80 \%$ of baseline BP, $160 \mathrm{~mm} \mathrm{Hg}$ in SBP and $90 \mathrm{~mm} \mathrm{Hg}$ in DBP, or $110 \mathrm{~mm} \mathrm{Hg}$ in the mean BP. The antihypertensive regimens including intravenous drugs such as labetalol, nicardipine, diltiazem, nitroglycerin, and nitroprusside are recommended [122]. Despite a recent report on benefits associated with lowering the BP to $140 \mathrm{~mm} \mathrm{Hg}$ during the acute phase, the supportive evidence is insufficient; hence, the BP should be gradually and cautiously reduced $[123,124]$.

\section{Secondary prevention of stroke}

HTN treatment as a measure of secondary prevention after stroke significantly reduces mortality and the recurrence of stroke or vascular diseases $[109,125,126]$. Regardless of the history of HTN, treatment of HTN after stroke significantly reduces the mortality and complications associated with HTN. Lifestyle modifications should be maintained in addition to the pharmacologic treatment. For selection of the optimal antihypertensive drugs, the individual characteristics of the patient such as the presence of extracranial cerebrovascular disease, kidney disease, heart disease, and diabetes should be considered. In a recent meta-analysis, a combination therapy using ACE inhibitors and diuretics was preferred [127].

\section{Aortic disease}

In patients with aortic aneurysm, it is strongly recommended to lower the BP to the lowest levels tolerated by the patient [128]. Beta-blockers are preferred owing to their ability to reduce the maximum ventricular ejection of the left ventricle, as well as the BP and heart rate, but there is no controlled study for non-Marfan origin [129]. In the acute aortic syndrome, including aortic dissection, the BP and heart rate should be controlled aggressively with a regimen that includes a beta-blocker [130].

\section{Erectile dysfunction}

Erectile dysfunction in hypertensive patients is considered to be one of the CV risk factors [131] associated with poor prognosis. Therefore, risk factors such as DM, dyslipidemia, and smoking should be controlled aggressively, and lifestyle modifications should be suggested to patients to reduce the CV risk [132]. However, most erectile dysfunction cases in hypertensive patients are not diagnosed by a doctor, and only a minority of patients seeks medical advice. Therefore, in order to improve CV prognosis with regard to erectile dysfunction, more cautious history taking is required to ensure it is incorporated in clinical decision making [133].

In general, the prevalence of erectile dysfunction in patients with HTN is reported to be $0 \%$ to $25 \%$, but its evaluation is difficult because of the impact of the underlying diseases. Erectile dysfunction related to the administration of a specific drug is usually observed within 4 weeks. If the association is clear, the drug could be replaced, but the possibility that the preexisting peripheral vascular disease is exaggerated should be kept in mind when the drug is replaced. Beta-blockers and diuretics are known to cause erectile dysfunction, and ACE inhibitors and calcium antagonists are neutral, whereas ARBs are sometimes reported to be beneficial [53].

With respect to the conventional beta-blockers administered for patients with erectile dysfunction, a vasodilating beta-blocker may be an alternative [53]. In patients with erectile dysfunction caused by antihypertensive drugs, the phosphodiesterase-5 (PDE5) inhibitor is relatively safe and effective and the additional BP lowering effect is negligible [133]. However, the BP after administration of PDE5 inhibitors should be clearly noted, and PDE5 inhibitors must not be coadministered with nitrates.

\section{Pregnancy}

High BP occurring during pregnancy can be divided into four categories: 1) chronic HTN in pregnancy: existing HTN or taking antihypertensive medication before the 20th week of pregnancy, 2) gestational HTN: new HTN diagnosed after the 20th week of pregnancy in the absence of proteinuria, 3) preeclampsia: HTN diagnosed after 20 weeks of pregnancy accompanied by proteinuria (albumin more than $300 \mathrm{mg}$ in 24-h urine or urine albumin/ creatinine ratio of $300 \mathrm{mg} / \mathrm{g}$ or greater), and 4) preeclampsia superimposed on chronic HTN: preeclampsia is diagnosed in the chronic HTN in pregnancy. According to the level of BP, it is classified as mild: 140 to $149 \mathrm{~mm} \mathrm{Hg} / 90$ to $99 \mathrm{~mm} \mathrm{Hg}$, moderate: 150 to $159 \mathrm{~mm} \mathrm{Hg} / 100$ to $109 \mathrm{~mm} \mathrm{Hg}$, and severe: 160/110 mm Hg or higher.

Generally, there are few controversies about the drug treatment for BP of $>160 / 110 \mathrm{~mm} \mathrm{Hg}$ or higher. A study reported that a patient with $\mathrm{BP}$ of $>150 / 95 \mathrm{~mm} \mathrm{Hg}$ is more likely to be hospitalized due to incident stroke during the peripartum period $[18,134]$. In uncomplicated pregnancy, because there is no evidence, [135] BP is controlled below $150 / 100 \mathrm{~mm} \mathrm{Hg}[136,137]$, but it is not recommended to lower DBP below $80 \mathrm{~mm} \mathrm{Hg}[137,138]$.

Antihypertensive drugs used during pregnancy are methyldopa, labetalol, and nifedipine [139]. The specific 
drugs are selected in consideration of the class of drugs previously taken, their side effects, and the risk of teratogenicity. Because beta-blockers may cause fetal growth retardation, it is preferable to use beta-blockers later in the pregnancy. Diuretics should be prescribed cautiously because they can decrease the volume of water in the body. Because ACE inhibitors or angiotensin blockers may increase the risk of congenital malformations in pregnancy, it is recommended to replace those drugs before pregnancy or when planning a pregnancy. If a pregnancy is detected during the administration of $\mathrm{ACE}$ inhibitors or angiotensin receptor blockers, they should be discontinued and replaced promptly. In emergency situations, such as preeclampsia, intravenous labetalol is recommended, but intravenous nitroprusside or nitroglycerin could be alternatives. After delivery, BP should be controlled below 140/90 mm Hg.

Gestational HTN and preeclampsia are associated with a relatively high risk of developing HTN in the future, and preeclampsia is a risk factor for CVD. Patients with a history of preeclampsia have about a twofold risk for ischemic heart disease, stroke, and venous thrombosis [140] and a fourfold risk for developing sustained HTN [141]. Especially in case of preeclampsia within 32 weeks of gestation, stillbirth, and fetal growth retardation, the risk for HTN increases much more. Thus, for HTN during pregnancy, active BP control and lifestyle modification even after delivery is strongly recommended.

\section{Women and hypertension}

In younger population, the woman has lower prevalence of HTN than the man. But after menopause, the prevalence of HTN in women increases rapidly that it catches up the prevalence in men in their 60s. And it becomes even higher than that in men in their 70s or 80s. As for age, the increase in pulse pressure is the same between men and women; however, the SBP and DBP are higher in women after menopause than before menopause. Care should be taken in the diagnosis of HTN in menopausal women, because white coat HTN occurs more frequently in these women.

After menopause, weight gain, hormonal changes, and psychological changes occur [142]. Especially, the deficiency of female hormones such as estrogen induces menopausal symptoms and many CV changes [143]. In the past, hormone replacement therapy (HRT) was widely recommended after menopause, but clinical studies found no preventive effects on CVD or it sometimes worsened, and therefore, HRT is no longer recommended for the purpose to prevent a CV event. Because HRT can increase BP, women who have a greater chance of developing HTN need to be carefully observed for a few months [144].

There is no difference in HTN treatment between women and men. Additionally, there is no difference in
$\mathrm{BP}$ reduction and drug effects between women and men [145]. Oral contraceptives can increase BP in some subjects, but the effects are not severe and the occurrence of accelerated or malignant HTN is rare. Family history of HTN, past history of HTN during pregnancy, potential kidney disease, obesity, or a longer period of oral contraceptive use increase the risk. Therefore, in the early period of oral contraceptive use, BP needs to be carefully monitored, while periodic measurements are recommended thereafter.

\section{Abbreviations \\ ACE: Angiotensin-converting enzyme; ARB: Angiotensin receptor blocker; BMI: Body mass index; BP: Blood pressure; CKD: Chronic kidney disease; CV: Cardiovascular; CVD: Cardiovascular diseases; DBP: Diastolic blood pressure; DM: Diabetes mellitus; HDL: High density lipoprotein; HRT: Hormone replacement therapy; HTN: Hypertension; KNHANES: Korean National Health and Nutrition Examination Survey; LVH: Left ventricular hypertrophy; PDE5: Phosphodiesterase 5; SBP: Systolic blood pressure; UKPDS: United Kingdom Prospective Diabetes Study.}

\section{Competing interests}

Preparation of this guideline is financially supported by the Korean Society of Hypertension.

\section{Acknowledgements}

On behalf of the committee of the clinical practice guidelines at the Korean Society of Hypertension, we thank professors Cheol-Ho Kim and Hyeon Chang Kim for their kind consultations. Additionally, we thank the officials of the The Korean Society of Internal Medicine, The Korean Geriatrics Society, The Korean Stroke Society, The Korean Diabetes Association, The Korean Society of Nephrology, and The Korean Society of Cardiology for their endorsement of this guideline.

\section{Author details}

'Department of Internal Medicine, Hanyang University College of Medicine, Seoul, Korea. ${ }^{2}$ Division of Cardiology, Department of Medicine, Cheil General Hospital, Dankook University College of Medicine, Seoul, Korea. ${ }^{3}$ Department of Internal Medicine, School of Medicine, Seoul National University, Bundang, Korea. ${ }^{4}$ Department of Internal Medicine, School of Medicine, Chonnam University, GwangJu, Korea. ${ }^{5}$ Division of Cardiology, Department of Internal Medicine, Kyungpook National University School of Medicine, 130 Dongdeok-ro, Jung-gu, Daegu 700-721, Korea. ${ }^{6}$ Division of Cardiology, Department of Internal Medicine, Ewha Womans University School of Medicine, Seoul, Korea. ${ }^{7}$ Division of Cardiology, Department of Internal Medicine, Dongkuk University College of Medicine, Ilsan, Korea.

Received: 2 December 2014 Accepted: 23 December 2014 Published online: 15 April 2015

\section{References}

1. Verdecchia P, Reboldi GP, Angeli F, Schillaci G, Schwartz JE, Pickering TG, et al. Short- and long-term incidence of stroke in white-coat hypertension. Hypertension. 2005;45:203-8.

2. Verdecchia P, Angeli F. The natural history of white-coat hypertension in the long term. Blood Press Monit. 2005;10:65-6.

3. Ohkubo T, Kikuya M, Metoki H, Asayama K, Obara T, Hashimoto J, et al. Prognosis of "masked" hypertension and "white-coat" hypertension detected by 24-h ambulatory blood pressure monitoring 10-year follow-up from the Ohasama study. J Am Coll Cardiol. 2005;46:508-15.

4. Alberti KG, Eckel RH, Grundy SM, Zimmet PZ, Cleeman Jl, Donato KA, et al. Harmonizing the metabolic syndrome: a joint interim statement of the International Diabetes Federation Task Force on Epidemiology and Prevention; National Heart, Lung, and Blood Institute; American Heart Association; World Heart Federation; International Atherosclerosis Society; and International Association for the Study of Obesity. Circulation. 2009;120:1640-5 
5. International Association for the Study of Obesity. The Asia-Pacific Perspective: redefining obesity and its treatment. West Pacific Region: WHO; 2000.

6. Lim S, Shin H, Song JH, Kwak SH, Kang SM, Won Yoon J, et al. Increasing prevalence of metabolic syndrome in Korea: the Korean National Health and Nutrition Examination Survey for 1998-2007. Diabetes Care. 2011;34:1323-8.

7. Cha MJ, Lee HY, Ahn SV, Han KR, Park JB, Lim SJ, et al. Prevalence and clinical characteristics of metabolic syndrome in Korean hypertensive patients. J Korean Soc Hypertens. 2009;15:37-44.

8. Gami AS, Witt BJ, Howard DE, Erwin PJ, Gami LA, Somers VK, et al. Metabolic syndrome and risk of incident cardiovascular events and death: a systematic review and meta-analysis of longitudinal studies. J Am Coll Cardiol. 2007:49:403-14.

9. Ford ES, Li C, Sattar N. Metabolic syndrome and incident diabetes: current state of the evidence. Diabetes Care. 2008;31:1898-904.

10. Cheung BM, Wat NM, Man YB, Tam S, Thomas GN, Leung GM, et al. Development of diabetes in Chinese with the metabolic syndrome: a 6-year prospective study. Diabetes Care. 2007;30:1430-6.

11. Mukai N, Doi Y, Ninomiya T, Hata J, Yonemoto K, Iwase M, et al. Impact of metabolic syndrome compared with impaired fasting glucose on the development of type 2 diabetes in a general Japanese population: the Hisayama study. Diabetes Care. 2009;32:2288-93.

12. American Diabetes Association. Standards of medical care in diabetes 2013. Diabetes Care. 2013;36 Suppl 1:S11-66.

13. Gress TW, Nieto FJ, Shahar E, Wofford MR, Brancati FL. Hypertension and antihypertensive therapy as risk factors for type 2 diabetes mellitus. Atherosclerosis risk in communities study. N Engl J Med. 2000;342:905-12.

14. Weycker D, Nichols GA, O'Keeffe-Rosetti M, Edelsberg J, Vincze G, Khan ZM, et al. Excess risk of diabetes in persons with hypertension. J Diabetes Complications. 2009;23:330-6.

15. Celik T, Iyisoy A, Kursaklioglu H, Kardesoglu E, Kilic S, Turhan H, et al. Comparative effects of nebivolol and metoprolol on oxidative stress, insulin resistance, plasma adiponectin and soluble P-selectin levels in hypertensive patients. J Hypertens. 2006;24:591-6.

16. Dhakam Z, Yasmin, McEniery CM, Burton T, Brown MJ, Wilkinson IB. A comparison of atenolol and nebivolol in isolated systolic hypertension. J Hypertens. 2008;26:351-6.

17. Bakris GL, Fonseca V, Katholi RE, McGill JB, Messerli FH, Phillips RA, et al. Metabolic effects of carvedilol vs metoprolol in patients with type 2 diabetes mellitus and hypertension: a randomized controlled trial. JAMA. 2004;292:2227-36.

18. Mancia G, Fagard R, Narkiewicz K, Redon J, Zanchetti A, Bohm M, et al. 2013 ESH/ ESC Guidelines for the management of arterial hypertension: the Task Force for the management of arterial hypertension of the European Society of Hypertension (ESH) and of the European Society of Cardiology (ESC). J Hypertens. 2013;31:1281-357.

19. Elliott WJ, Meyer PM. Incident diabetes in clinical trials of antihypertensive drugs: a network meta-analysis. Lancet. 2007;369:201-7.

20. Mann JF, Schmieder RE, McQueen M, Dyal L, Schumacher H, Pogue J, et al. Renal outcomes with telmisartan, ramipril, or both, in people at high vascular risk (the ONTARGET study): a multicentre, randomised, double-blind, controlled trial. Lancet. 2008;372:547-53.

21. Adler Al, Stratton IM, Neil HA, Yudkin JS, Matthews DR, Cull CA, et al, Association of systolic blood pressure with macrovascular and microvascular complications of type 2 diabetes (UKPDS 36): prospective observational study. BMJ. 2000;321:412-9.

22. Officers ALLHAT, Coordinators for the ALLHAT Collaborative Research Group. Major outcomes in high-risk hypertensive patients randomized to angiotensin-converting enzyme inhibitor or calcium channel blocker vs diuretic: The Antihypertensive and Lipid-Lowering Treatment to Prevent Heart Attack Trial (ALLHAT). JAMA. 2002;288:2981-97.

23. Beulens JW, Patel A, Vingerling JR, Cruickshank JK, Hughes AD, Stanton A, et al. Effects of blood pressure lowering and intensive glucose control on the incidence and progression of retinopathy in patients with type 2 diabetes mellitus: a randomised controlled trial. Diabetologia. 2009;52:2027-36.

24. Lindholm LH, Ibsen $H$, Dahlof B, Devereux RB, Beevers $G$, de Faire U, et al. Cardiovascular morbidity and mortality in patients with diabetes in the Losartan Intervention For Endpoint reduction in hypertension study (LIFE): a randomised trial against atenolol. Lancet. 2002;359:1004-10.

25. Yusuf S, Sleight P, Pogue J, Bosch J, Davies R, Dagenais G. Effects of an angiotensin-converting-enzyme inhibitor, ramipril, on cardiovascular events in high-risk patients. The Heart Outcomes Prevention Evaluation Study Investigators. N Engl J Med. 2000;342:145-53.

26. Lenfant C, Chobanian AV, Jones DW, Roccella EJ, Joint National Committee on the Prevention DE, Treatment of High Blood P. Seventh report of the Joint National Committee on the Prevention, Detection, Evaluation, and Treatment of High Blood Pressure (JNC 7): resetting the hypertension sails. Hypertension. 2003;41:1178-9.

27. Cushman WC, Evans GW, Byington RP, Goff Jr DC, Grimm Jr RH, Cutler JA, et al. Effects of intensive blood-pressure control in type 2 diabetes mellitus. N Engl J Med. 2010;362:1575-85.

28. Turnbull F, Neal B, Algert C, Chalmers J, Chapman N, Cutler J, et al. Effects of different blood pressure-lowering regimens on major cardiovascular events in individuals with and without diabetes mellitus: results of prospectively designed overviews of randomized trials. Arch Intern Med. 2005;165:1410-9.

29. Beckett NS, Peters R, Fletcher AE, Staessen JA, Liu L, Dumitrascu D, et al. Treatment of hypertension in patients 80 years of age or older. N Engl J Med. 2008;358:1887-98.

30. Whelton PK, Appel $\amalg$, Espeland MA, Applegate WB, Ettinger Jr WH, Kostis $\mathrm{JB}$, et al. Sodium reduction and weight loss in the treatment of hypertension in older persons: a randomized controlled trial of nonpharmacologic interventions in the elderly (TONE). TONE Collaborative Research Group. JAMA. 1998;279:839-46.

31. Liu L, Zhang Y, Liu G, Li W, Zhang X, Zanchetti A, et al. The Felodipine Event Reduction (FEVER) Study: a randomized long-term placebo-controlled trial in Chinese hypertensive patients. J Hypertens. 2005;23:2157-72.

32. JATOS Study Group. Principal results of the Japanese trial to assess optimal systolic blood pressure in elderly hypertensive patients (JATOS). Hypertens Res. 2008;31:2115-27.

33. Prevention of stroke by antihypertensive drug treatment in older persons with isolated systolic hypertension. Final results of the Systolic Hypertension in the Elderly Program (SHEP). SHEP Cooperative Research Group. Jama 1991; 265:3255-64.

34. Staessen JA, Fagard R, Thijs L, Celis H, Arabidze GG, Birkenhager WH, et al. Randomised double-blind comparison of placebo and active treatment for older patients with isolated systolic hypertension. The Systolic Hypertension in Europe (Syst-Eur) Trial Investigators. Lancet. 1997;350:757-64.

35. Wing LM, Reid CM, Ryan P, Beilin LJ, Brown MA, Jennings GL, et al. A comparison of outcomes with angiotensin-converting-enzyme inhibitors and diuretics for hypertension in the elderly. N Engl J Med. 2003;348:583-92

36. Lithell H, Hansson L, Skoog I, Elmfeldt D, Hofman A, Olofsson B, et al. The Study on Cognition and Prognosis in the Elderly (SCOPE): principal results of a randomized double-blind intervention trial. J Hypertens. 2003;21:875-86.

37. Blood Pressure Lowering Treatment Trialists C, Turnbull F, Neal B, Ninomiya T, Algert C, Arima $\mathrm{H}$, et al. Effects of different regimens to lower blood pressure on major cardiovascular events in older and younger adults: meta-analysis of randomised trials. BMJ. 2008:336:1121-3.

38. Hanes DS, Weir MR. The beta blockers: are they as protective in hypertension as in other cardiovascular conditions? J Clin Hypertens (Greenwich). 2001;3:236-43.

39. Prisant LM. Challenges for beta-blockers as first-line therapy for elderly hypertensive patients. Postgrad Med. 2002;112:34-41.

40. Whitlock G, Lewington S, Sherliker P, Clarke R, Emberson J, Halsey J, et al Body-mass index and cause-specific mortality in 900000 adults: collaborative analyses of 57 prospective studies. Lancet. 2009;373:1083-96.

41. Lewington S, Clarke R, Qizilbash N, Peto R, Collins R, Prospective SC. Age-specific relevance of usual blood pressure to vascular mortality: a meta-analysis of individual data for one million adults in 61 prospective studies. Lancet. 2002;360:1903-13.

42. Mancia G, Messerli F, Bakris G, Zhou Q, Champion A, Pepine CJ. Blood pressure control and improved cardiovascular outcomes in the International Verapamil SR-Trandolapril Study. Hypertension. 2007;50:299-305.

43. Law MR, Morris JK, Wald NJ. Use of blood pressure lowering drugs in the prevention of cardiovascular disease: meta-analysis of 147 randomised trials in the context of expectations from prospective epidemiological studies. BMJ. 2009:338:b1665.

44. Borghi C, Bacchelli S, Esposti DD, Bignamini A, Magnani B, Ambrosioni E. Effects of the administration of an angiotensin-converting enzyme inhibitor during the acute phase of myocardial infarction in patients with arterial hypertension. SMILE Study Investigators. Survival of Myocardial Infarction Long-term Evaluation. Am J Hypertens. 1999;12:665-72. 
45. Tocci G, Sciarretta S, Volpe M. Development of heart failure in recent hypertension trials. J Hypertens. 2008;26:1477-86.

46. Turnbull F, Blood Pressure Lowering Treatment Trialists C. Effects of different blood-pressure-lowering regimens on major cardiovascular events: results of prospectively-designed overviews of randomised trials. Lancet. 2003;362:1527-35.

47. Raphael CE, Whinnett Zl, Davies JE, Fontana M, Ferenczi EA, Manisty CH, et al. Quantifying the paradoxical effect of higher systolic blood pressure on mortality in chronic heart failure. Heart. 2009;95:56-62.

48. Rutten FH, Zuithoff NP, Hak E, Grobbee DE, Hoes AW. Beta-blockers may reduce mortality and risk of exacerbations in patients with chronic obstructive pulmonary disease. Arch Intern Med. 2010;170:880-7.

49. Massie BM, Carson PE, McMurray JJ, Komajda M, McKelvie R, Zile MR, et al. Irbesartan in patients with heart failure and preserved ejection fraction. N Engl J Med. 2008;359:2456-67.

50. Camm AJ, Kirchhof P, Lip GY, Schotten U, Savelieva I, Ernst S, et al. Guidelines for the management of atrial fibrillation: the Task Force for the Management of Atrial Fibrillation of the European Society of Cardiology (ESC). Eur Heart J. 2010:31:2369-429.

51. Kirchhof P, Lip GY, Van Gelder IC, Bax J, Hylek E, Kaab S, et al. Comprehensive risk reduction in patients with atrial fibrillation: Emerging diagnostic and therapeutic options. Executive summary of the report from the 3rd AFNET/EHRA consensus conference. Thromb Haemost. 2011;106:1012-9.

52. Camm AJ, Lip GY, De Caterina R, Savelieva I, Atar D, Hohnloser SH, et al. 2012 focused update of the ESC Guidelines for the management of atrial fibrillation: an update of the 2010 ESC Guidelines for the management of atrial fibrillation. Developed with the special contribution of the European Heart Rhythm Association. Eur Heart J. 2012;33:2719-47.

53. Manolis A, Doumas M. Sexual dysfunction: the 'prima ballerina' of hypertension-related quality-of-life complications. J Hypertens. 2008;26:2074-84

54. Arima H, Anderson C, Omae T, Woodward M, MacMahon S, Mancia G, et al. Effects of blood pressure lowering on intracranial and extracranial bleeding in patients on antithrombotic therapy: the PROGRESS trial. Stroke. 2012;43:1675-7.

55. Ducharme A, Swedberg K, Pfeffer MA, Cohen-Solal A, Granger CB, Maggioni AP, et al. Prevention of atrial fibrillation in patients with symptomatic chronic heart failure by candesartan in the Candesartan in Heart failure: Assessment of Reduction in Mortality and morbidity (CHARM) program. Am Heart J. 2006:152:86-92.

56. Vermes E, Tardif JC, Bourassa MG, Racine N, Levesque S, White M, et al. Enalapril decreases the incidence of atrial fibrillation in patients with left ventricular dysfunction: insight from the Studies Of Left Ventricular Dysfunction (SOLVD) trials. Circulation. 2003;107:2926-31.

57. Wachtell K, Lehto M, Gerdts E, Olsen MH, Hornestam B, Dahlof B, et al. Angiotensin II receptor blockade reduces new-onset atrial fibrillation and subsequent stroke compared to atenolol: the Losartan Intervention For End Point Reduction in Hypertension (LIFE) study. J Am Coll Cardiol. 2005;45:712-9.

58. Schmieder RE, Kjeldsen SE, Julius S, McInnes GT, Zanchetti A, Hua TA, et al. Reduced incidence of new-onset atrial fibrillation with angiotensin I receptor blockade: the VALUE trial. J Hypertens. 2008;26:403-11.

59. Cohn JN, Tognoni G, Investigators VHFT. A randomized trial of the angiotensin-receptor blocker valsartan in chronic heart failure. N Engl J Med. 2001;345:1667-75.

60. Yusuf S, Teo K, Anderson C, Pogue J, Dyal L, Copland I, et al. Effects of the angiotensin-receptor blocker telmisartan on cardiovascular events in high-risk patients intolerant to angiotensin-converting enzyme inhibitors: a randomised controlled trial. Lancet. 2008:372:1174-83.

61. Yusuf S, Healey JS, Pogue J, Chrolavicius S, Flather M, Hart RG, et al. Irbesartan in patients with atrial fibrillation. N Engl J Med. 2011;364:928-38.

62. Tveit A, Grundvold I, Olufsen M, Seljeflot I, Abdelnoor M, Arnesen H, et al. Candesartan in the prevention of relapsing atrial fibrillation. Int J Cardiol. 2007;120:85-91.

63. Disertori M, Latini R, Barlera S, Franzosi MG, Staszewsky L, Maggioni AP, et al. Valsartan for prevention of recurrent atrial fibrillation. N Engl J Med. 2009;360:1606-17.

64. Schneider MP, Hua TA, Bohm M, Wachtell K, Kjeldsen SE, Schmieder RE. Prevention of atrial fibrillation by renin-angiotensin system inhibition a meta-analysis. J Am Coll Cardiol. 2010;55:2299-307.
65. Nasr IA, Bouzamondo A, Hulot JS, Dubourg O, Le Heuzey JY, Lechat P. Prevention of atrial fibrillation onset by beta-blocker treatment in heart failure: a meta-analysis. Eur Heart J. 2007;28:457-62

66. Swedberg K, Zannad F, McMurray JJ, Krum H, van Veldhuisen DJ, Shi H, et al. Eplerenone and atrial fibrillation in mild systolic heart failure: results from the EMPHASIS-HF (Eplerenone in Mild Patients Hospitalization And Survlval Study in Heart Failure) study. J Am Coll Cardiol. 2012;59:1598-603.

67. Zanchetti A, Crepaldi G, Bond MG, Gallus G, Veglia F, Mancia G, et al. Different effects of antihypertensive regimens based on fosinopril or hydrochlorothiazide with or without lipid lowering by pravastatin on progression of asymptomatic carotid atherosclerosis: principal results of PHYLLIS-a randomized double-blind tri. Stroke. 2004;35:2807-12.

68. Zanchetti A, Bond MG, Hennig M, Neiss A, Mancia G, Dal Palu C, et al. Calcium antagonist lacidipine slows down progression of asymptomatic carotid atherosclerosis: principal results of the European Lacidipine Study on Atherosclerosis (ELSA), a randomized, double-blind, long-term trial. Circulation. 2002;106:2422-7.

69. Ong KT, Delerme S, Pannier B, Safar ME, Benetos A, Laurent S, et al. Aortic stiffness is reduced beyond blood pressure lowering by short-term and I ong-term antihypertensive treatment: a meta-analysis of individual data in 294 patients. J Hypertens. 2011;29:1034-42.

70. Karalliedde J, Smith A, DeAngelis L, Mirenda V, Kandra A, Botha J, et al. Valsartan improves arterial stiffness in type 2 diabetes independently of blood pressure lowering. Hypertension. 2008;51:1617-23.

71. Shahin Y, Khan JA, Chetter I. Angiotensin converting enzyme inhibitors effect on arterial stiffness and wave reflections: a meta-analysis and meta-regression of randomised controlled trials. Atherosclerosis. 2012;221:18-33.

72. Kampus P, Serg M, Kals J, Zagura M, Muda P, Karu K, et al. Differential effects of nebivolol and metoprolol on central aortic pressure and left ventricular wall thickness. Hypertension. 2011:57:1122-8.

73. Guerin AP, Blacher J, Pannier B, Marchais SJ, Safar ME, London GM. Impact of aortic stiffness attenuation on survival of patients in end-stage renal failure. Circulation. 2001;103:987-92.

74. Murabito JM, Evans JC, D'Agostino Sr RB, Wilson PW, Kannel WB. Temporal trends in the incidence of intermittent claudication from 1950 to 1999. Am J Epidemiol. 2005;162:430-7.

75. De Buyzere ML, Clement DL. Management of hypertension in peripheral arterial disease. Prog Cardiovasc Dis. 2008;50:238-63.

76. Paravastu SC, Mendonca DA, da Silva A. Beta blockers for peripheral arterial disease. Eur J Vasc Endovasc Surg. 2009;38:66-70.

77. Paravastu SC, Mendonca DA, Da Silva A. Beta blockers for peripheral arterial disease. Cochrane Database Syst Rev. 2013;9:CD005508.

78. Radack K, Deck C. Beta-adrenergic blocker therapy does not worsen intermittent claudication in subjects with peripheral arterial disease. A meta-analysis of randomized controlled trials. Arch Intern Med. 1991;151:1769-76.

79. Singer DR, Kite A. Management of hypertension in peripheral arteria disease: does the choice of drugs matter? Eur J Vasc Endovasc Surg. 2008;35:701-8.

80. Kidney Disease: Improving Global Outcomes (KDIGO) CKD Work Group. KDIGO 2012 Clinical Practice Guideline for the Evaluation and Management of Chronic Kidney Disease. Kidney Int Suppl. 2013;3:151.

81. Kim S, Song YR, Chin HJ, Oh YK, Oh KH, Joo KW, et al. The prevalence of chronic kidney disease and the predictors of decreased kidney function in hypertensive patients. Korean J Nephrol. 2008;27:8.

82. Kim YJ, Kwak C. Prevalence and associated risk factors for cardiovascular disease: Findings from the 2005, 2007 Korea National Health and Nutrition Examination Survey. Korean J Health Promot. 2011;83:7.

83. Wheeler DC, Becker GJ. Summary of KDIGO guideline. What do we really know about management of blood pressure in patients with chronic kidney disease? Kidney Int. 2013:83:377-83.

84. Chobanian AV, Bakris GL, Black HR, Cushman WC, Green LA, Izzo Jr JL, et al. Seventh report of the Joint National Committee on Prevention, Detection, Evaluation, and Treatment of High Blood Pressure. Hypertension. 2003:42:1206-52

85. Kdoqi. KDOQI Clinical Practice Guidelines and Clinical Practice Recommendations for Diabetes and Chronic Kidney Disease. Am J Kidney Dis. 2007:49:S12-154.

86. Upadhyay A, Earley A, Haynes SM, Uhlig K. Systematic review: blood pressure target in chronic kidney disease and proteinuria as an effect modifier. Ann Intern Med. 2011;154:541-8. 
87. Wright Jr JT, Bakris G, Greene T, Agodoa LY, Appel LJ, Charleston J, et al. Effect of blood pressure lowering and antihypertensive drug class on progression of hypertensive kidney disease: results from the AASK trial. JAMA. 2002;288:2421-31.

88. Ruggenenti P, Perna A, Loriga G, Ganeva M, Ene-lordache B, Turturro M, et al. Blood-pressure control for renoprotection in patients with non-diabetic chronic renal disease (REIN-2): multicentre, randomised controlled trial. Lancet. 2005:365:939-46

89. Peterson JC, Adler S, Burkart JM, Greene T, Hebert LA, Hunsicker LG, et al Blood pressure control, proteinuria, and the progression of renal disease. The modification of diet in renal disease study. Ann Intern Med. 1995;123:754-62.

90. Jafar TH, Stark PC, Schmid CH, Landa M, Maschio G, de Jong PE, et al. Progression of chronic kidney disease: the role of blood pressure control, proteinuria, and angiotensin-converting enzyme inhibition: a patient-level meta-analysis. Ann Intern Med. 2003;139:244-52.

91. Maschio G, Alberti D, Janin G, Locatelli F, Mann JF, Motolese M, et al. Effect of the angiotensin-converting-enzyme inhibitor benazepril on the progression of chronic renal insufficiency. The Angiotensin-Converting-Enzyme Inhibition in Progressive Renal Insufficiency Study Group. N Engl J Med. 1996;334:939-45.

92. Ruggenenti P, Perna A, Benini R, Bertani T, Zoccali C, Maggiore Q, et al. In chronic nephropathies prolonged ACE inhibition can induce remission: dynamics of time-dependent changes in GFR. Investigators of the GISEN Group. Gruppo Italiano Studi Epidemiologici in Nefrologia. J Am Soc Nephrol. 1999;10:997-1006.

93. Randomised placebo-controlled trial of effect of ramipril on decline in glomerular filtration rate and risk of terminal renal failure in proteinuric, non-diabetic nephropathy. The GISEN Group (Gruppo Italiano di Studi Epidemiologici in Nefrologia). Lancet 1997;349:1857-63.

94. Kidney Disease: Improving Global Outcomes (KDIGO) Blood Pressure Work Group. KDIGO clinical practice guideline for the management of blood pressure in chronic kidney disease. Kidney Int Suppl. 2012;2:75.

95. Boudville N, Ward S, Benaroia M, House AA. Increased sodium intake correlates with greater use of antihypertensive agents by subjects with chronic kidney disease. Am J Hypertens. 2005;18:1300-5.

96. Chen L, Davey Smith G, Harbord RM, Lewis SJ. Alcohol intake and blood pressure: a systematic review implementing a Mendelian randomization approach. PLoS Med. 2008;5:e52.

97. Gelber RP, Kurth T, Kausz AT, Manson JE, Buring JE, Levey AS, et al. Association between body mass index and CKD in apparently healthy men. Am J Kidney Dis. 2005:46:871-80.

98. Jones DW, Kim JS, Andrew ME, Kim SJ, Hong YP. Body mass index and blood pressure in Korean men and women: the Korean National Blood Pressure Survey. J Hypertens. 1994;12:1433-7.

99. Kosmadakis GC, John SG, Clapp EL, Viana JL, Smith AC, Bishop NC, et al. Benefits of regular walking exercise in advanced pre-dialysis chronic kidney disease. Nephrol Dial Transplant. 2012;27:997-1004.

100. Krikken JA, Laverman GD, Navis G. Benefits of dietary sodium restriction in the management of chronic kidney disease. Curr Opin Nephrol Hypertens. 2009;18:531-8

101. Whelton SP, Chin A, Xin X, He J. Effect of aerobic exercise on blood pressure: a meta-analysis of randomized, controlled trials. Ann Intern Med. 2002;136:493-503.

102. Yoon J, Kim KK, Hwang IC, Lee KS, Suh HS. Association between body mass index, abdominal obesity defined by waist circumference criteria, and estimated glomerular filtration rate in healthy Korean adults: 2007 the Korea National Health and Nutrition Survey. Korean J Obes. 2011;20:8.

103. Brenner BM, Cooper ME, de Zeeuw D, Keane WF, Mitch WE, Parving HH, et al. Effects of losartan on renal and cardiovascular outcomes in patients with type 2 diabetes and nephropathy. N Engl J Med. 2001;345:861-9.

104. Jafar TH, Schmid CH, Landa M, Giatras I, Toto R, Remuzzi G, et al. Angiotensin-converting enzyme inhibitors and progression of nondiabetic renal disease. A meta-analysis of patient-level data. Ann Intern Med. 2001;135:73-87.

105. Lewis EJ, Hunsicker LG, Clarke WR, Berl T, Pohl MA, Lewis JB, et al. Renoprotective effect of the angiotensin-receptor antagonist irbesartan in patients with nephropathy due to type 2 diabetes. N Engl J Med. 2001;345:851-60.

106. Acelajado MC, Oparil S. Hypertension in the elderly. Clin Geriatr Med. 2009;25:391-412
107. Benvenuto LJ, Krakoff LR. Morbidity and mortality of orthostatic hypotension: implications for management of cardiovascular disease. Am J Hypertens. 2011;24:135-44.

108. Wu JS, Yang YC, Lu FH, Wu CH, Chang CJ. Population-based study on the prevalence and correlates of orthostatic hypotension/hypertension and orthostatic dizziness. Hypertens Res. 2008;31:897-904.

109. Lawes CM, Bennett DA, Feigin VL, Rodgers A. Blood pressure and stroke: an overview of published reviews. Stroke. 2004;35:776-85.

110. Psaty BM, Lumley T, Furberg CD, Schellenbaum G, Pahor M, Alderman MH, et al. Health outcomes associated with various antihypertensive therapies used as first-line agents: a network meta-analysis. JAMA. 2003;289:2534-44.

111. Campbell NR, Poirier L, Tremblay G, Lindsay P, Reid D, Tobe SW, et al. Canadian Hypertension Education Program: the science supporting New 2011 CHEP recommendations with an emphasis on health advocacy and knowledge translation. Can J Cardiol. 2011;27:407-14.

112. Wiysonge CSBH, Mayosi BM, Maroney R. Mbewu A. Volmink J. Beta-blockers for hypertension: Opie LH; 2007

113. Aronow WS, Frishman WH. Treatment of hypertension and prevention of ischemic stroke. Curr Cardiol Rep. 2004;6:124-9.

114. Qureshi Al, Bliwise DL, Bliwise NG, Akbar MS, Uzen G, Frankel MR. Rate of 24-hour blood pressure decline and mortality after spontaneous intracerebral hemorrhage: a retrospective analysis with a random effects regression model. Crit Care Med. 1999;27:480-5.

115. Schrader J, Luders S, Kulschewski A, Berger J, Zidek W, Treib J, et al. The ACCESS study: evaluation of acute Candesartan Cilexetil therapy in stroke survivors. Stroke. 2003;34:1699-703.

116. Hankey GJ. Lowering blood pressure in acute stroke: the SCAST trial. Lancet. 2011;377:696-8

117. 2011 Clinical guidelines for stroke in Korea. http://www.stroke-crc.or.kr/뇌졸 중진료지침\%2020130322.pdf

118. Jauch EC, Saver JL, Adams Jr HP, Bruno A, Connors JJ, Demaerschalk BM, et al. Guidelines for the early management of patients with acute ischemic stroke: a guideline for healthcare professionals from the American Heart Association/American Stroke Association. Stroke. 2013;44:870-947.

119. Larrue V, von Kummer R, del Zoppo G, Bluhmki E. Hemorrhagic transformation in acute ischemic stroke. Potential contributing factors in the European cooperative acute stroke study. Stroke. 1997:28:957-60.

120. Intracerebral hemorrhage after intravenous t-PA therapy for ischemic stroke. The NINDS t-PA Stroke Study Group. Stroke 1997;28:2109-18.

121. Adams Jr HP, del Zoppo G, Alberts MJ, Bhatt DL, Brass L, Furlan A, et al. Guidelines for the early management of adults with ischemic stroke: a guideline from the American Heart Association/American Stroke Association Stroke Council, Clinical Cardiology Council, Cardiovascular Radiology and Intervention Council, and the Atherosclerotic Peripheral Vascular Disease and Quality of Care Outcomes in Research Interdisciplinary Working Groups: the American Academy of Neurology affirms the value of this guideline as an educational tool for neurologists. Stroke. 2007;38:1655-711.

122. Ohwaki K, Yano E, Nagashima H, Hirata M, Nakagomi T, Tamura A. Blood pressure management in acute intracerebral hemorrhage: relationship between elevated blood pressure and hematoma enlargement. Stroke. 2004;35:1364-7.

123. Anderson CS, Heeley E, Huang Y, Wang J, Stapf C, Delcourt C, et al. Rapid blood-pressure lowering in patients with acute intracerebral hemorrhage. N Engl J Med. 2013;368:2355-65.

124. Morgenstern LB, Hemphill 3rd JC, Anderson C, Becker K, Broderick JP, Connolly Jr ES, et al. Guidelines for the management of spontaneous intracerebral hemorrhage: a guideline for healthcare professionals from the American Heart Association/American Stroke Association. Stroke. 2010:41:2108-29.

125. PATS Collaborating Group. Poststroke antihypertensive treatment study. A preliminary result. Chin Med J (Engl). 1995;108:8.

126. Rashid P, Leonardi-Bee J, Bath P. Blood pressure reduction and secondary prevention of stroke and other vascular events: a systematic review. Stroke. 2003;34:2741-8.

127. Progress Collaborative Group. Randomised trial of a perindopril-based blood-pressure-lowering regimen among 6,105 individuals with previous stroke or transient ischaemic attack. Lancet. 2001;358:1033-41.

128. Shores J, Berger KR, Murphy EA, Pyeritz RE. Progression of aortic dilatation and the benefit of long-term beta-adrenergic blockade in Marfan's syndrome. N Engl J Med. 1994;330:1335-41. 
129. Elefteriades JA, Farkas EA. Thoracic aortic aneurysm clinically pertinent controversies and uncertainties. J Am Coll Cardiol. 2010;55:841-57.

130. Braverman AC. Acute aortic dissection: clinician update. Circulation. 2010;122:184-8.

131. Dong JY, Zhang YH, Qin LQ. Erectile dysfunction and risk of cardiovascular disease: meta-analysis of prospective cohort studies. J Am Coll Cardiol. 2011;58:1378-85.

132. Gupta BP, Murad MH, Clifton MM, Prokop L, Nehra A, Kopecky SL. The effect of lifestyle modification and cardiovascular risk factor reduction on erectile dysfunction: a systematic review and meta-analysis. Arch Intern Med. 2011;171:1797-803.

133. Scranton RE, Lawler E, Botteman M, Chittamooru S, Gagnon D, Lew R, et al. Effect of treating erectile dysfunction on management of systolic hypertension. Am J Cardiol. 2007;100:459-63.

134. Kuklina EV, Tong X, Bansil P, George MG, Callaghan WM. Trends in pregnancy hospitalizations that included a stroke in the United States from 1994 to 2007: reasons for concern? Stroke. 2011:42:2564-70.

135. Abalos E, Duley L, Steyn DW, Henderson-Smart DJ. Antihypertensive drug therapy for mild to moderate hypertension during pregnancy. Cochrane Database Syst Rev 2007:CD002252.

136. Regitz-Zagrosek V, Blomstrom Lundqvist C, Borghi C, Cifkova R, Ferreira R, Foidart JM, et al. ESC Guidelines on the management of cardiovascular diseases during pregnancy: the Task Force on the Management of Cardiovascular Diseases during Pregnancy of the European Society of Cardiology (ESC). Eur Heart J. 2011;32:3147-97.

137. Excellence $\mathrm{NIfHaC}$. Hypertension in pregnancy. The management of hypertensive disorders during pregnancy 2011.

138. Mustafa R, Ahmed S, Gupta A, Venuto RC. A comprehensive review of hypertension in pregnancy. J Pregnancy. 2012;2012:105918.

139. National Institute for Health and Clinical Excellence. Hypertension (CG127): clinical management of primary hypertension in adults. http://www.nice.org.uk/guidance/CG127

140. Bellamy L, Casas JP, Hingorani AD, Williams DJ. Pre-eclampsia and risk of cardiovascular disease and cancer in later life: systematic review and meta-analysis. BMJ. 2007;335:974.

141. McDonald SD, Malinowski A, Zhou Q, Yusuf S, Devereaux PJ. Cardiovascular sequelae of preeclampsia/eclampsia: a systematic review and meta-analyses. Am Heart J. 2008;156:918-30.

142. Reckelhoff JF, Fortepiani LA. Novel mechanisms responsible for postmenopausal hypertension. Hypertension. 2004;43:918-23.

143. Staessen JA, Celis H, Fagard R. The epidemiology of the association between hypertension and menopause. J Hum Hypertens. 1998;12:587-92.

144. Chasan-Taber L, Willett WC, Manson JE, Spiegelman D, Hunter DJ, Curhan G, et al. Prospective study of oral contraceptives and hypertension among women in the United States. Circulation. 1996;94:483-9.

145. Turnbull F, Woodward M, Neal B, Barzi F, Ninomiya T, Chalmers J, et al. Do men and women respond differently to blood pressure-lowering treatment? Results of prospectively designed overviews of randomized trials. Eur Heart J. 2008:29:2669-80

\section{Submit your next manuscript to BioMed Central and take full advantage of:}

- Convenient online submission

- Thorough peer review

- No space constraints or color figure charges

- Immediate publication on acceptance

- Inclusion in PubMed, CAS, Scopus and Google Scholar

- Research which is freely available for redistribution 